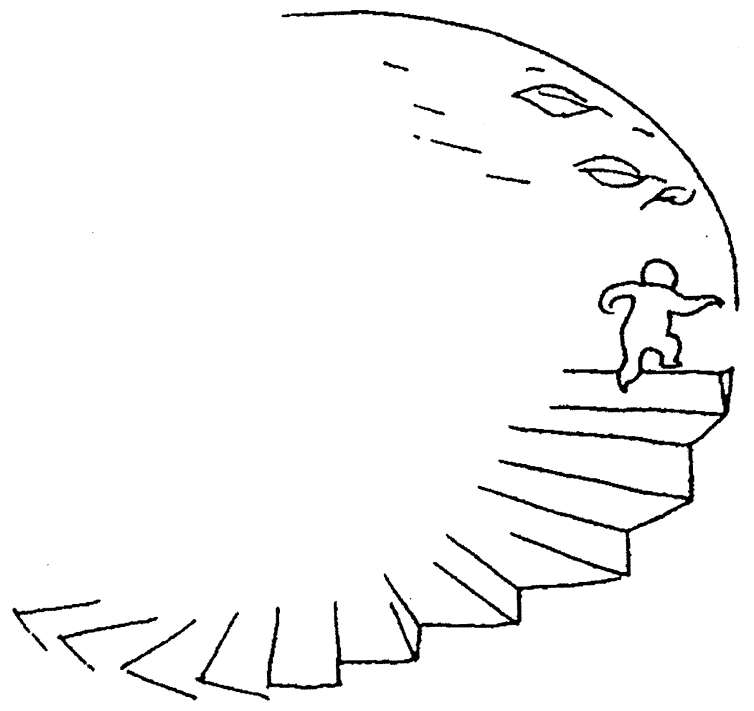

\title{
THE TWELVE STAGES
}

Approach,

Appraise,

Defend,

$$
\text { Apply. }
$$

Defeat,

Defy.

Review,

Renew,

Remove.

Adopt,

Adapt,

Improve.

\section{Piet Hein}

Copyright $(\subset)$ Piet Hein Illustrationn \& Grook

Reprinted with Kind Permission from Piet Hein a/s, Middelfart, Denmark 